\title{
PERANCANGAN E-LEARNING BERBASIS WEB MENGGUNAKAN FRAMEWORK CODEIGNITER
}

\author{
FATHUR RAHMAN, S.Kom., M.Kom ${ }^{1)}$ \\ ,fathurti@uniska-bjm.ac.id, \\ Dr. SILVIA RATNA, S.Kom., M.Kom ${ }^{2)}$ \\ silvia.ratna@uniska-bjm.ac.id
}

Fakultas Teknologi Informasi

Universitas Islam Kalimantan Muhammad Arsyad Al Banjari Banjarmasin

\begin{abstract}
Abstrak
Suatu Proses pembelajaran secara E-learning merupqkan perkembangan teknologi yang dapat melengkapai model pembelajaran yang ada sekarang ini yaitu model konvensional tatap muka sehingga dengan adanya elearning dapat membantu terlaksananya sebuah sistem pembelajaran secara efisien. Bila E-Learning yang berjalan tidak baik atau bahkan masih dilakukan secara manual maka sulit untuk mendapatkan hasil yang cepat dan tepat dalam waktu yang singkat. E-Learning berbasis web merupakan suatu alternatif media pembelajaran untuk menunjang dan melengkapi model pembelajaran konvensional, Sebuah e-Leraning yang di bangun menggunakan Framework CodeIgniter merupakan pengembangan web e-learning tanpa menggunakan framework sehingga dengan model framework akan mendapatkan hasilyang sangat baik dan menarik serta hasil tampilan web yang lebih baik dan dinamis juga menjadikan website menjadi lebih kompatibel dengan web browser. Hasil Web E-Learning menggunakan framework CodeIgniter dapat memudahkan pengguna dalam berinteraksi dan lebih memeberikan hasil yang efisien di dalam proses pembelajaran.
\end{abstract}

Keywords : Web, E-learning, CodeIgniter dan MySQL.

\section{PENDAHULUAN}

Teknologi adalah sebuah pengetahuan yang diperuntukan untuk dapat menciptakan kumpulan alat, suatu tindakan untuk pengolahan dan mengekstrak suatu benda secara keseluruhan dan sarana untuk menyiapkan barang yang diperlukan untuk kelangsungan serta menciptakan kenyamanan di linkungan manusia.

Perkembangan teknologi yang terbaru di dalam lingkungan manusia antara lain printer atau mesin cetak, telepon, dan Internet, telah meningkatkan efisiensi dan produktifitas manusia untuk dapat

Jurnal Ilmiah"Technologia" berkomunikasi dan memudahkan manusia untuk berinteraksi secara cepat dan nyaman secara keseluruhan. Akan tetapi, tidaklah semua dalam kemajuan teknologi digunakan oleh manusia untuk kepentingan yang baik, tetapi ada juga perkembangan teknologi menghasilkan pengembangan senjata perusak atau penghancur yang semakin banyak berlangsung didalam sepanjang peradaban sejarah, dari senjata yang paling sederhana sampai senjata penghancur hebat (nuklir).

Situs web (Inggris: website) adalah suatu halaman web yang saling berhubungan 
antara satu dengan yang lainnya dimana data web tersebut berada pada server yang sama dimana berisikan macam-macam kumpulan suatu informasi yang bisa disediakan untuk perorangan, kelompok, dan organisasi.

E-learning atau bisa juga disebut e-learning adalah suatu cara baru dalam pembelajaran serta pengajaran untuk memudahkan atau membantu proses tersebut supaya lebih memudahkan dan dilihat dari sisi kemudahan dan efisiensi tersebut memang sangat menguntungkan bagi penggunanya. E-learning adalah hal yang dasar dalam penerapan teknologi dan juga suatu konsekuensi yang logis dari pengembangan teknologi informasi dan komunikasi sekarang ini . Dengan e-learning, pengajar dalam mengajar peserta didik atau siswa / mahasiswa tidak perlu duduk di dalam kelas untuk mendengarkan setiap pernyataan pengajar secara langsung. E-learning juga bisa mempersingkat waktu pengajaran, dan tentu saja mengurangi sejumlah biaya yang seharusnya dikeluarkan oleh penyelenggara sehingga penyelenggaraannya pengajaran bisa lebih efisien.

CodeIgniter adalah merupakan sebuah aplikasi terbuka atau open source yang berfondasi dari framework PHP dengan model MVC atau juga biasa disebut Model View Controller yang digunakan untuk membangun suatu website dinamik dengan menggunakan kode PHP. CodeIgniter membantu memudahkan pengembang atau para developer untuk bisa membuat suatu aplikasi berbasis website dengan sangatberbasi web dengan cepat dan cepat dan memberikan kemudahan dibandingkan dengan membuat Jurnal Ilmiah"Technologia” menggunakan koding PHP murni atau membuat dari awal pemprograman. CodeIgniter di keluarkan atau dirilis pada saat pertama kali pada 28 Februari 2006. Versi terbaru dan stabil terakhir adalah versi v3.1.8.

\section{METODE PENELITIAN}

Metode pengembangan aplikasi atau sistem yang digunakan dalam perancangan sistem dan Pembuatan Web E-Learning Berbasis Framework CodeIgniter memiliki langkah-langkah sebagai berikut :

1. Melakukan Pengumpulan data tentang informasi tentang E-Learning dan CodeIgniter

2. Perancangan / Desain Web dengan menggunakan koding PHP dan data base Mysql.

3. Mengimplementasikan Framework CodeIgniter ke dalam Website E-Learning yang telah dibuat.

4. Hasil proses pada pembuatan Web ELearning menyesuaikan dengan banyaknya data Dosen, Mahasiswa dan Materi dari Mata Kuliah.

5. Testing atau pengujian dilakukan untuk menemukan error atau bug yang ada di dalam sistem.

6. Perawatan atau maintenance terhadap We E-Learning harus Rutin dilakukan supaya Web tetap beroperasi dengan baik dan handal dalam penggunaannya. 


\section{HASIL DAN PEMBAHASAN}

\section{a. Hasil Penelitian}

Berdasarkan analisis dan serta perancangan sistem yang telah dilakukan dimana membuat website tersebut dengan mulai dari rancangan tampilan menu, rancangan database, diagram konteks, tabel data, form input dan form report atau laporan maka hasil penelitian yang berjudul "Perancangan E-Learning Berbasis Website Menggunakan Framework CodeIgniter sebagai berikut:

\section{1). Tampilan Halaman Utama Untuk User}

Tampilan ini adalah halaman utama atau login saat pengunjung mengakses web elearning ini. Hanya pengguna yang mempunya username dan passwaord saja yang dapat memasuki web elearning ini, pengguna umum dapat melihat-lihat informasi dan mendaftar elearning yang ada pada halaman tampilan utama.

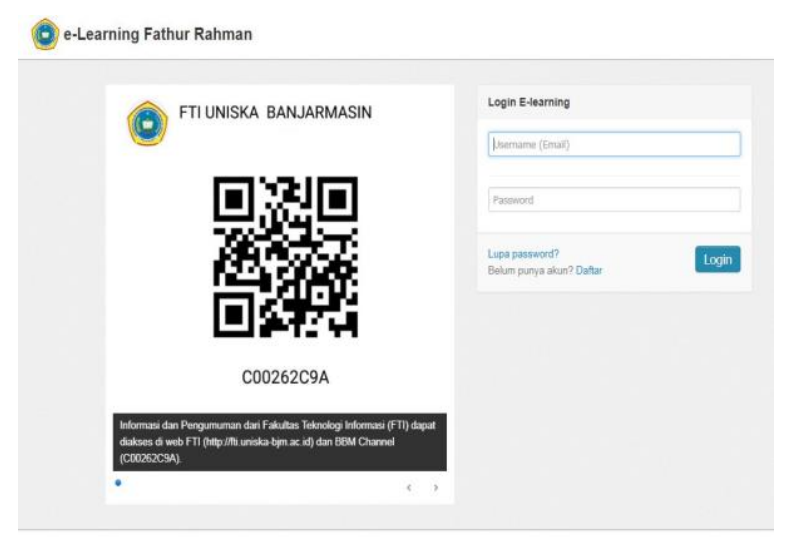

Gambar 1 Hasil Tampilan Halaman Login

\section{2) Hasil Tampilan Daftar Peserta}

Ini adalah tampilan yang akan tampil setelah user akan mendaftar sebagai peserta elearning sehingga user bisa masuk atau login pada web elearning tersebut.

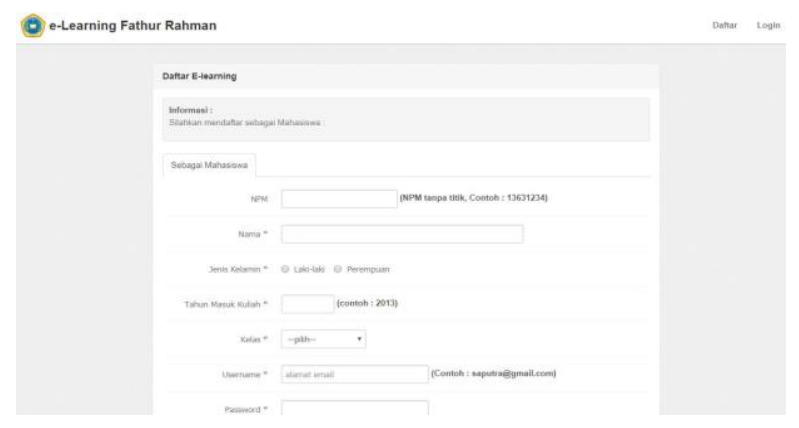

Gambar 2 Hasil Tampilan Halaman Pendaftaran

3) Hasil Tampilan Pembagian Kelas

Ini adalah tampilan halaman web untuk pembagian kelas elearning

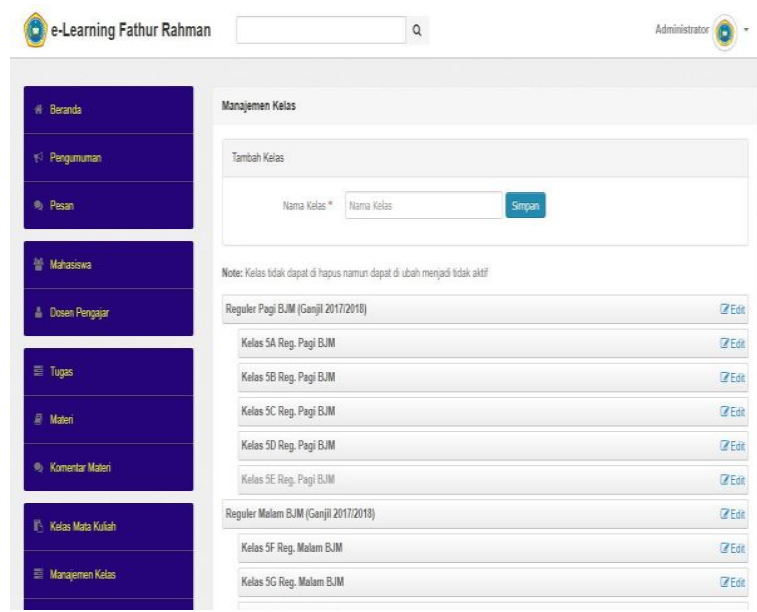

Gambar 3. Tampilan Halaman Pembagian Kelas 
4) Hasil Tampilan Menambah Soal Ujian

Ini adalah tampilan halaman web untuk menambah soal ujian untuk mahasiswa dari dosen pengampu.
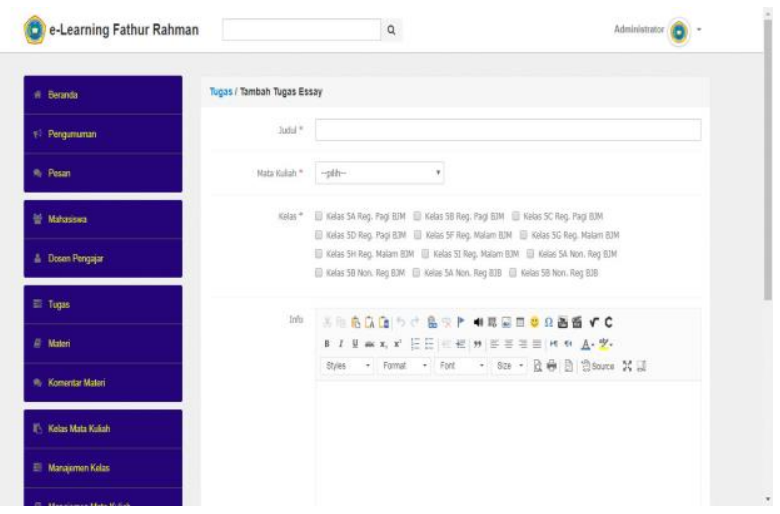

Gambar 4. Tampilan Halaman Menambah Soal

$$
\text { Ujian }
$$

\section{5) Hasil Tampilan Pengaturan}

Ini adalah tampilan halaman web untuk pengaturan setting web elearning.
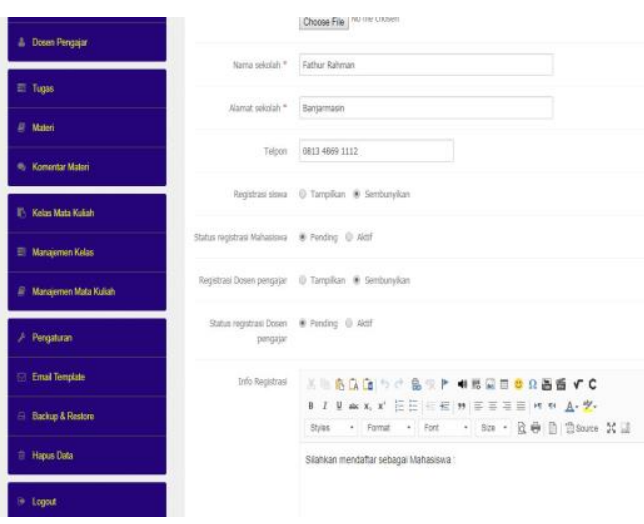

Gambar 4.9. Tampilan Halaman Pengaturan

\section{b. Pembahasan}

Setelah melalui tahapan pengujian web elearning untuk memastikan apakah web elearning yang di buat sudah sesuai dengan rencana perancangan sistem. Hal ini dapat diperlihatkan dengan hasil yang sesuai dengan pengharapan dari pembuat web dan meminimalkan kesalahan. Untuk pengujian kali ini menggunakan data sampel beberapa mahasiswa dan dosen untuk melihat hasil yang nyata dan langsung dapat diberikan masukan dari mahasiswa maupun dosen, sebelum web tersebut diimplementasikan secara online / internet. Sebagai pembanding dalam penelitian ini dilakukan analisis data dari pengajar dan pengguna web elearning (mahasiswa) pada saat sebelum implementasi web elearning yang dibuat dan sesudah implementasi web eleaning yang telah dibut maka didapatkan data kuantitatif sebagai berikut.

Tabel 1. Skoring Level Hasil Pembelajaran ELearning Sebelum Implementasi Web E-Learning

\begin{tabular}{|l|r|r|r|r|r|}
\hline No. & $\begin{array}{c}\text { Kesiap } \\
\text { an E- } \\
\text { Learni } \\
\text { ng }\end{array}$ & $\begin{array}{c}\text { Pengetah } \\
\text { uan } \\
\text { tentang } \\
\text { E- } \\
\text { learning }\end{array}$ & $\begin{array}{c}\text { Penggu } \\
\text { naan } \\
\text { Web } \\
\text { E- } \\
\text { learnin } \\
\mathrm{g}\end{array}$ & $\begin{array}{c}\text { Kesediaa } \\
\text { n Akses } \\
\text { Materi } \\
\text { Pembelaj } \\
\text { aran }\end{array}$ & $\begin{array}{c}\text { Pengguna } \\
\text { an Materi } \\
\text { Pembelaj } \\
\text { aran }\end{array}$ \\
\hline $\begin{array}{l}\text { Peng } \\
\text { ajar }\end{array}$ & $85 \%$ & $92 \%$ & $87 \%$ & $80 \%$ & $89 \%$ \\
\hline $\begin{array}{l}\text { Mah } \\
\text { asisw } \\
\text { a }\end{array}$ & $83 \%$ & $90 \%$ & $79 \%$ & $70 \%$ & $81 \%$ \\
\hline
\end{tabular}

Tabel 2. Skoring Level Hasil Pembelajaran E-Learning Sesudah Implementasi Web E-Learning

\begin{tabular}{|l|r|r|r|r|r|}
\hline No. & $\begin{array}{c}\text { Kesiap } \\
\text { an E- } \\
\text { Learni } \\
\text { ng }\end{array}$ & $\begin{array}{c}\text { Pengetah } \\
\text { uan } \\
\text { tentang } \\
\text { E- } \\
\text { learning }\end{array}$ & $\begin{array}{c}\text { Penggu } \\
\text { naan } \\
\text { Web } \\
\text { E- } \\
\text { learnin } \\
\mathrm{g}\end{array}$ & $\begin{array}{c}\text { Kesediaa } \\
\text { n Akses } \\
\text { Materi } \\
\text { Pembelaj } \\
\text { aran }\end{array}$ & $\begin{array}{c}\text { Pengguna } \\
\text { an Materi } \\
\text { Pembelaj } \\
\text { aran }\end{array}$ \\
\hline $\begin{array}{l}\text { Peng } \\
\text { ajar }\end{array}$ & $95 \%$ & $95 \%$ & $96 \%$ & $91 \%$ & $97 \%$ \\
\hline $\begin{array}{l}\text { Mah } \\
\text { asisw } \\
\text { a }\end{array}$ & $90 \%$ & $93 \%$ & $94 \%$ & $89 \%$ & $95 \%$ \\
\hline
\end{tabular}




\section{KESIMPULAN}

\section{a. Kesimpulan}

Berdasarkan dari penelitian yang telah dilaksanakan mengenai Perancangan Elearning Berbasis Website menggunakan suatu Framework CodeIgniter, maka dapat diambil kesimpulan sebagai berikut:

1. Kita dapat melakukan update atau pemutakhiran data atau bahan-bahan pembelajaran yang menjadi tugas seorang pengajar yang menyesuaikan dari tujuan perkembangan teknologi yang terkini pada keilmuan yang terbaru.

2. Dengan adanya web elearning maka kita dapat mengembangkan aplikasi yang dapat membantu penelitian guna meningkatkan wawasan dalam bidang web dan elearning.

3. Mengontrol secara efisien kegiatan pembelajaran peserta.

4. Interaksi antara pengajar dan peserta elearning lebih menarik dan menyenangkan (tidak monoton)

\section{b. Saran}

Perancangan E-Learning berbasis Web menggunakan Framework CodeIgniter ini masih adanya terdapat kekurangan. Oleh Karena itu perlu perbaikan dan pengembangan sistem dikemudian hari, maka saran yang diberikan untuk penelitian selanjutnya adalah sebagai berikut:

1. Website E-Learning yang sudah dibuat bisa di hostingkan di pengelola hosting secara online yang tersedia di internet.

2. Untuk melakukan hosting maka perlu didaftarkan nama domain yang mudah diingat sehingga mempermudah peserta e-learning untuk mendaftar / login.

3. Apabila sudah di hostingkan (online) maka peserta /mahasiswa dipersilahkan untuk mendaftar dan dapat mengikuti sistem pembelajaran secara e-learning.

4. Dengan tersedia web e-learning maka bisa atau dapat tersampaikannya bahan ajar atau materi pengajaran kepada peserta atau mahasiswa dengan menggunakan media internet, intranet atau media jaringan komputer lain.

\section{REFERENSI}

AH Sutopo. 2007. Pemrograman Macromedia Flash dengan PHP dan MySQL. Yogyakarta: Graha Ilmu.

Basuki, AP, 2010, Membuat Web Berbasis PHP dengan mengunakan Framework Codeigniter, Lokomedia, Yogyakarta.

B Raharjo. 2011. Belajar Otodidak Membuat Database Menggunakan MySQL. Bandung: Informatika.

B Sidik. 2012. Framework CodeIgniter. Bandung: Informatika.

E Kurniawan. 2010. Cepat Mahir ASP.NET 3,5 Untuk Membuat Aplikasi Web Interaktif. Yogyakarta: Andi.

Heni T. Agnes, 2007, Mahir dalam waktu 7 Hari: menggunakan Adobe Dreamweaver 8 dan PHP, Tim Divisi Penelitian dan Pengembangan, ANDI Yogyakarta dan MADCOMS 
Jogiyanto. HM, 2003, Analisis dan Desain Sistem Informasi, Andi Yogjakarta, Yogjakarta.

.Lukmanul Hakim, 2008, Membongkar Trik Rahasia Para Master PHP, Lokomedia.

Riyanto. 2013. Membuat suatu Web Store dengan menggunakan Framework CodeIgniter, MySQL \& jQuery Mobile. Yogyakarta: Andi.

https://id.wikipedia.org/wiki/CodeIgniter, Diakses Juli 2017

https://id.wikipedia.org/wiki/Pembelajaran_elektro nik, Diakses September 2017

https://id.wikipedia.org/wiki/World_Wide_Web, Diakses September 2017 